\title{
Clinical Features and Treatments of Carpal Bone Cysts
}

\section{Chul-Hyung Lee ${ }^{1}$, Dong-Hyuk Sun ${ }^{1}$, Youn-Min Lee ${ }^{2}$, Suk-Hwan Song', Seung-Koo Rhee ${ }^{1}$ \\ ${ }^{1}$ Department of Orthopedic Surgery, Sun General Hospital, Daejeon, Korea \\ ${ }^{2}$ Department of Orthopedic Surgery, Yeouido St. Mary's Hospital, The Catholic University of Korea College of Medicine, Seoul, Korea}

Received: December 31, 2013

Revised: February 24, 2014

Accepted: February 26, 2014

Correspondence to: Seung-Koo Rhee Department of Orthopedic Surgery, Sun General Hospital, 29 Mokchung-ro Chunggu, Daejeon 301-725, Korea

TEL: +82-42-220-8460

FAX: +82-42-252-1911

E-mail: skrhee@catholic.ac.kr
Purpose: A total of 27 carpal bone cysts were analyzed for their sites, relations of other wrist soft tissue ganglions and their results of treatment were evaluated. Methods: Twenty-seven carpal bone cysts in 20 patients (bilateral 5, multiple 2) from February 2002 to June 2013 were evaluated. Mean follow-up period was 16.6 months. We investigated etiological classification, the site of carpal bone cyst, and their relationship with soft tissue ganglion in same wrist. Pain, range of motion, radiographic changes, and their satisfaction after treatment were assessed postoperatively.

Results: The carpal bone cysts occurred mainly at the radial wrist axial ray on the lunate (12 cases), scaphoid (6 cases), and triquetrum (5 cases), trapezium (2 cases), and capitate (2 cases). Based on the magnetic resonance imaging (MRI) findings in 25 cases, we classified carpal bone cysts into 4 distinct types; type I with purely intraosseous lesion (16 cases), type II with bone cyst associated cortical perforations (6 cases), type III with coexisting soft tissue ganglion communicating with intra-osseous lesion ( 2 cases), and type IV with coexisting soft tissue ganglion non-communicating intraosseous lesions ( 1 case).

Conclusion: The carpal bone cysts can be classified by MRI into 4 distinct types. The purely intraosseous type is most common, suggesting the intrinsic cause in the development of carpal bone cyst.

Keywords: Bone cyst, Carpal bone
This is an Open Access article distributed under the terms of the Creative Commons Attribution Non-Commercial License (http://creativecommons.org/ licenses/bync/3.0/) which permits unrestricted noncommercial use, distribution, and reproduction in any medium, provided the original work is properly cited.

\section{서론}

수근부의 연부조직 결절종은 비교적 흔한 질환이지만 수근 골 내에 발생한 골내 낭종은 드물다 ${ }^{1-6}$. 또한 수근골 골낭종은 타 부위 골격계 골낭종에 비하여 유병률이 낮고 연구 보고가 적으며, 대부분 수근골 골낭종과 연부조직 결절종이 동일 부 위에서 연결되어 발생되는, 발생기전의 가능성을 보고 하는 경우가 많다 ${ }^{3-12}$.
수근골 골낭종은 대개 양성 낭종으로, 대개는 무증상이며 방사선 검사상 우연히 발견되는 편이나, 반면 만성 완관절 통 증을 유발시키는 원인중의 하나이다. 일반적인 골낭종은 퇴행 성 관절염이나 류마티스 관절염과 호발하여 생기는 경우가 많 으나 단일 방사선상 투과성 골용해 병변이며 심한 통증을 동 반하는 경우는 드물다. 감별진단 해야할 수근골내 질병들로는 유골종(osteoid osteoma), 골 거대세포종(giant cell tumor), 내연골종(enchondroma), 골모세포종(osteoblastoma), 월상 


\section{J Korean Soc Surg Hand Vol. 19, No. 1, March 2014}

골 연화증(Kienbock's disease) 등이 있다 ${ }^{1,3}$.

수근골 골낭종의 발생 원인으로는 수근골내 결합조직인 활 액막의 퇴화로 인한다는 내인성 가설과, 외력으로 인한 수근 골의 미세골절, 또는 활액이나 인접한 연부조직 결절종이 수 근골의 골내 침범에 의한다는 외인성 가설이 대두되고 있지만 확립되어 있지는 않으며, 그 외 세부적인 병인으로 외상, 관절 낭의 탈장, 점액변성(mucoid degeneration), 간엽세포(mesenchymal cell)의 골수내 화생(intramedullary metaplasia) 등이 거론되고 있다 ${ }^{1,3,4,6,12}$.

이에 저자들은 과거 10 년간 치험한 수근골 골낭종 환자들을 수술 전 자기공명영상(magnetic resonance imaging, MRI) 과 수술 소견, 장기 추적 결과를 토대로 그 임상 양상과 치료 결과를 알아보고자 하였다.

\section{대상 및 방법}

2002년 2월부터 2013년 7월까지 치험한 총 20명(양측 5예) 의 환자, 25 완관절을 대상으로 한 후향적 연구로서, 1 개 이상 의 수근골에서 발생한 2 예를 포함하여, 총 27 예의 수근골 골 낭종을 치료후 평균 16.6 개월간 추적 관찰하였다. 첫 진단은 단순방사선 검사에 의해 확진되어, 경계가 잘 구분되는 방사 선 투과성의 병변에 주변부의 경화가 동반되는 특징을 보였 다. 3 개월 이상 보전적 치료에 반응 하지 않는 환자에서 수술 적 치료를 시행하였으며, 반대편 손목 수술 후 증상이 호전되 어 수술하지 않은 2예를 제외한, 총 25예에서 소파 및 골이식 술, 단순 소파술을 시행하였으며, 수술을 시행한 모든 예에서 병리학적 검사를 시행하여 최종 진단을 내렸다. 환자들의 나 이, 성별, 직업, 방사선학적 소견, 컴퓨터단층촬영(computed tomography, CT), MRI 등을 이용한 발생기전을 추적하였 고, 외상을 포함한 증상의 발생경위, 우세수에서의 발생여부, 수근골 발생부위, 증상 발현 후 치료까지의 지연기간과 이유 를 조사하였으며, 최종 추시 시 완관절의 동통, 수술 전·후 운동범위, 방사선상 소견, 환자의 만족도 등을 평가하였다. 수 술 후 3 주간 부목고정을 시행하였고, 추적 단순방사선 검사를 통해 골격변화를 추적하였다. 척골 양성 변이에 따른 월상골 의 충돌증후군이나 무혈성괴사, 중증 완관절 골관절염 등이 동반된 경우는 연구 대상에서 제외하였다.

\section{결과}

20 명의 환자 중 여자가 15 명, 남자는 5 명이었다. 평균연령 은 44.3세였으며 우측이 13예, 좌측이 2예 양측이 5예였다.
넘어지거나 강한 외력에 의한 경우 2 예를 제외하고는, 외상력 이 없거나 경미한 사회생활에서의 단순 외상이 대부분을 차지 하였다.

외래 초진 시 주 호소는 경미한 간헐적 완관절의 동통과 운 동 제한이 18 예, 2 예는 원위 요골골절과 동반되어 우연히 발 견되었다. 처음 증상이 있은 후부터 외래 첫 방문 시까지 걸린 기간은 평균 47.8 개월로, 지연 이유는 증상이 경미하였거나 소염제등의 보존적 치료를 받았기 때문으로 분석되었고, 전 예에서 혈액 검사상 이상은 없었다. 우세수와 일치하는 경우 는 18 예, 일치하지 않는 경우는 2 예였다.

발생 부위는 수근골 중 월상골이 12 예, 삼각골이 5 예, 주상 골 6 예 및 유두골 2예, 대다각골 2예로 완관절의 축성압력 (axial loading)이 가해지는 요골측 수근열(radial ray) 측에 호발하였다(Fig. 1). 수술은 시행하지 않은 2예를 제외한 총 25예의 골낭종 MRI 및 수술소견은 네 가지 형태로 명확한 구 분이 가능하여, 단독으로 골낭종만이 있는 제I형(16예), 골낭 종이 피질골의 천공을 유발한 제II형(6예), 동일 완관절 연부 조직 결절종과 인접 동반된 제III형(2예), 그리고 동일 완관절 내 타 부위의 연부조직 결절종이 동반된 제VI형(1예)으로 분류 되었다(Table 1). 병적 골절이 동반된 예는 없었다.

수술적 치료는 25 예에서 시행하였으며 2예는 보전적 치료 를 하였다. 수술적 치료로는 소파 및 자가 골이식술을 시행하 였다. 수술 후 평균 16.6 개월 관찰하였으며 골이식은 전 예에 서 골유합된 소견을 보였다. 25예 중 8예(32\%)에서 수술 후 2 개월까지 경한 완관절 운동제한을 호소하였으며 6 예에서 노동 시 동통을 호소하였다. 수술 전 후 시각적 통증 강도 비율 척 도(visual analogue scale)는 평균 65에서 13으로 감소하였 다. 20 명 중 1 명을 제외하고 19 명이 수술 후 6 주 이후 원래의

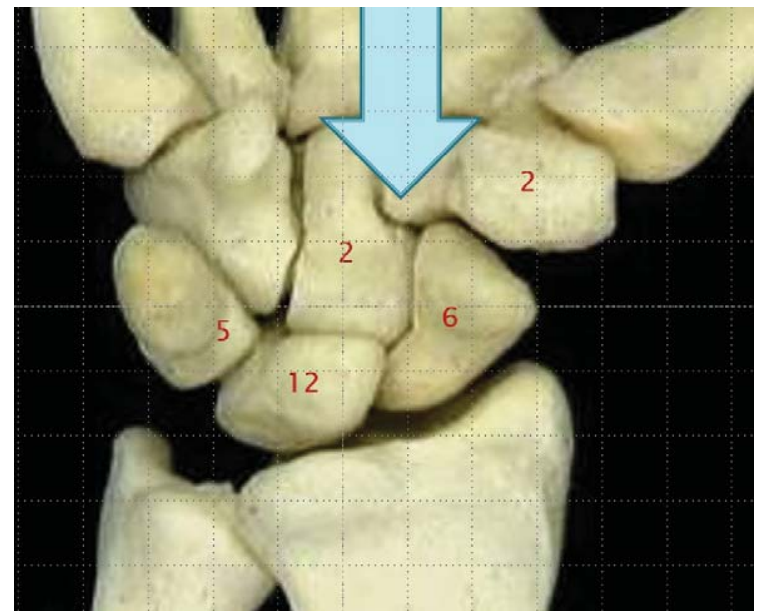

Fig. 1. The location of carpal bone cysts. 
Chul-Hyung Lee, et al. Clinical Features and Treatments of Carpal Bone Cysts

Table 1. Classification of carpal bone cyst (total 25 cases)

\begin{tabular}{ll}
\hline Type I & Purely intra-0sseous bone cyst (16 cases, 64\%) \\
Type II & Intra-0sseous bone cyst with cortical perforation (6 cases, 24\%) \\
Type III & Coexisting soft tissue ganglion communicating with intra-0sseous bone cyst (2 cases, $8 \%)$ \\
Type IV & Soft tis tissue ganglion non-communicating with intra-osseous bone cyst (1 case, 4\%) \\
\hline
\end{tabular}

직업에 복귀하였다.

\section{1. 증례보고 \\ 1) 증례 1}

평소 손목을 많이 사용하는 33세 여자 간호사로 약탕기로 약을 빻은 후 양 손목 통증 및 운동범위 제한을 주소로 내원하 였다. 단순방사선촬영상 삼각골(triquetrum)의 골낭종이 관 찰되며 피질골 파열 소견은 없었다(Fig. 2). 저자들의 분류상 제I형에 해당하며, 소파 및 자가골 이식술을 시행하였다. 수술 후 8주경 골유합을 얻었고, 완관절 운동범위도 정상으로 회복 되었다.

\section{2) 증례 2}

약 10 년간 손을 많이 쓰는 일을 해온 40 세 여자 환자로 최근 4 개월 전부터 외상력 없이 악화된 우측 완관절 동통성 운동제 한을 주소로 내원하였다. 시행한 단순방사선 촬영상 주상골의 골낭종이 관찰되며(Fig. $3 \mathrm{~A}), \mathrm{CT}$ 소견상 골피질이 천공되어 있었다(Fig. $3 \mathrm{~B})$. 완관절의 연부조직 결절종은 병합되어 있지 않아 저자들의 분류상 제II형에 해당한다. 단순 골소파 및 자 가골 이식술 3 개월 후 정상 골유합과 완관절 기능회복을 얻
었다.

3) 증례 3

37 세 여자환자로 운전 중 급정거 후 발생한 우측 완관절 염

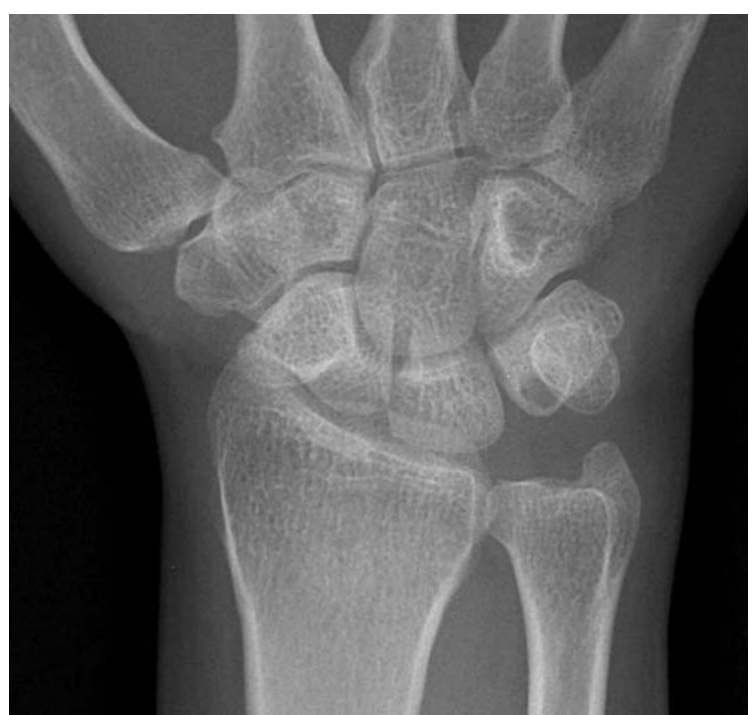

Fig. 2. Anteroposterior radiograph of wrist shows radiolucent lesion on triquetrum, purely intraosseous bone cyst.
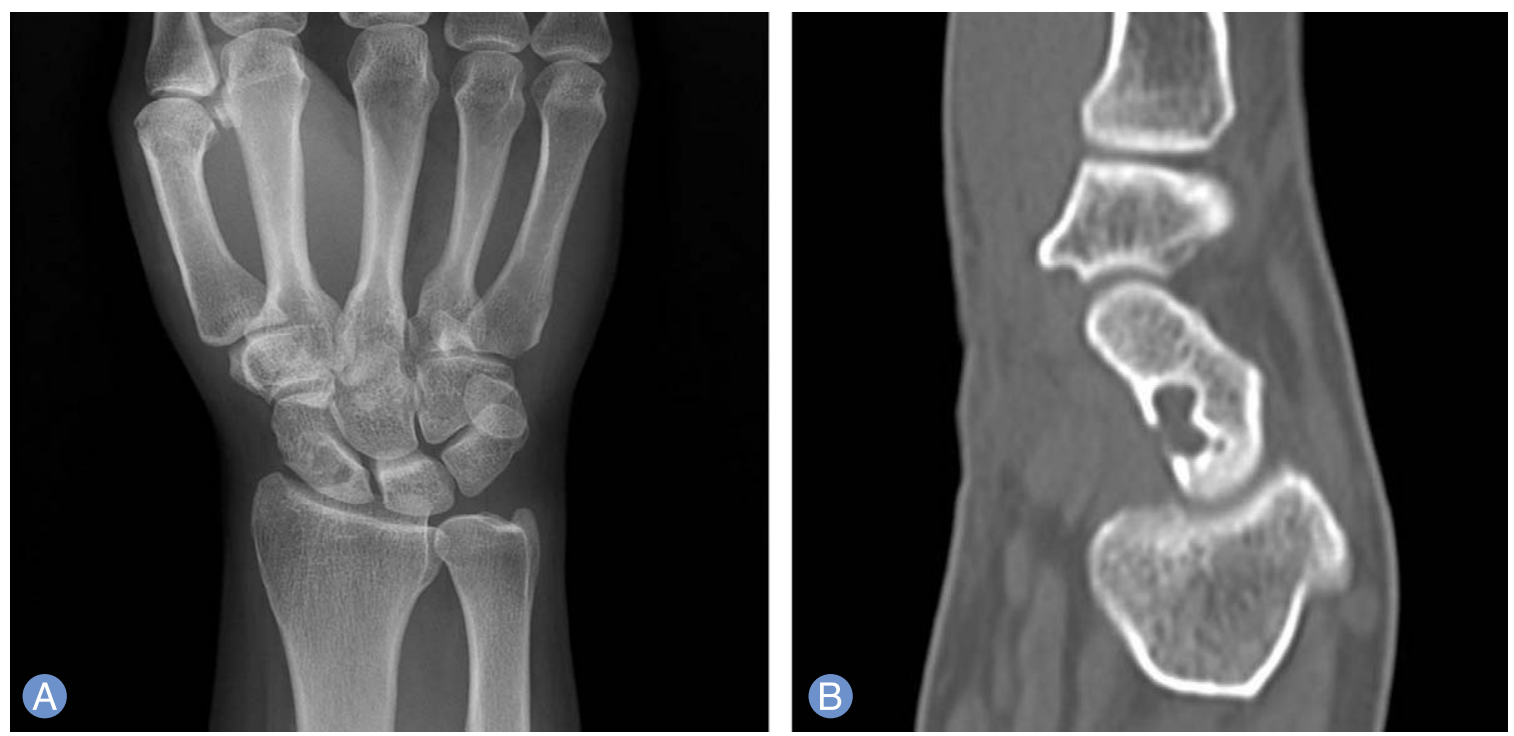

Fig. 3. (A) Anteroposterior radiograph of wrist shows radiolucent lesion on scaphoid. (B) Saggital computed tomography showing the lytic intraosseous ganglion on scaphoid with a sclerotic margin, expansion and perforating of the cortex. 
J Korean Soc Surg Hand Vol. 19, No. 1, March 2014

좌로 내원하였다. 시행한 단순방사선 촬영상 주상골의 골낭종 이 관찰되며(Fig. $4 \mathrm{~A}$ ), MRI상 연부조직의 결절종이 주상골 골낭종과 인접하여 서로 미세 교통(micro-connection)된 것 으로 판단되었다(Fig. 4B). 저자들의 분류상 제III형에 해당하 며, 연부조직 낭종의 절제와 함께 주상골 골낭종의 소파 및 자 가골 이식으로 치료하였으며, 수술 2개월 후 정상 완관절 기능 을 회복하였다.

\section{4) 증례 4}

52 세 남성의 제 3 수근-중수지관절에 발생한 완관절 결절종 의 수술차 내원하여 시행한 단순방사선촬영상 두상골의 골낭 종 소견 보이고(Fig. $5 \mathrm{~A}$ ), MRI상 두상골 골낭종과 연결되어
있지 않은 완관절 결절종이 관찰된다(Fig. $5 \mathrm{~B}$ ). 환자는 결절종 발견이전부터 완관절의 운동시 동통을 호소하였다. 저자들의 분류상 제IV형에 해당하며, 골소파 및 자가골이식으로 수술 후 4개월에 양호한 치료결과를 얻었다. 두상골내 낭종의 조직 소견도 결절종의 조직과 동일하였다(Fig. $5 \mathrm{C}$ ).

\section{고찰}

본 연구에서 저자들은 단순방사선 및 MRI 검사, 수술 소견 등을 종합하여 수근골 골낭종의 발생기전과 병변 특징을 4 가 지로 분류하였다(Table 1). 즉 단독으로 골낭종만 발생한 경우 를 type I, 16예(purely intraosseous lesion, case 1) (Fig.
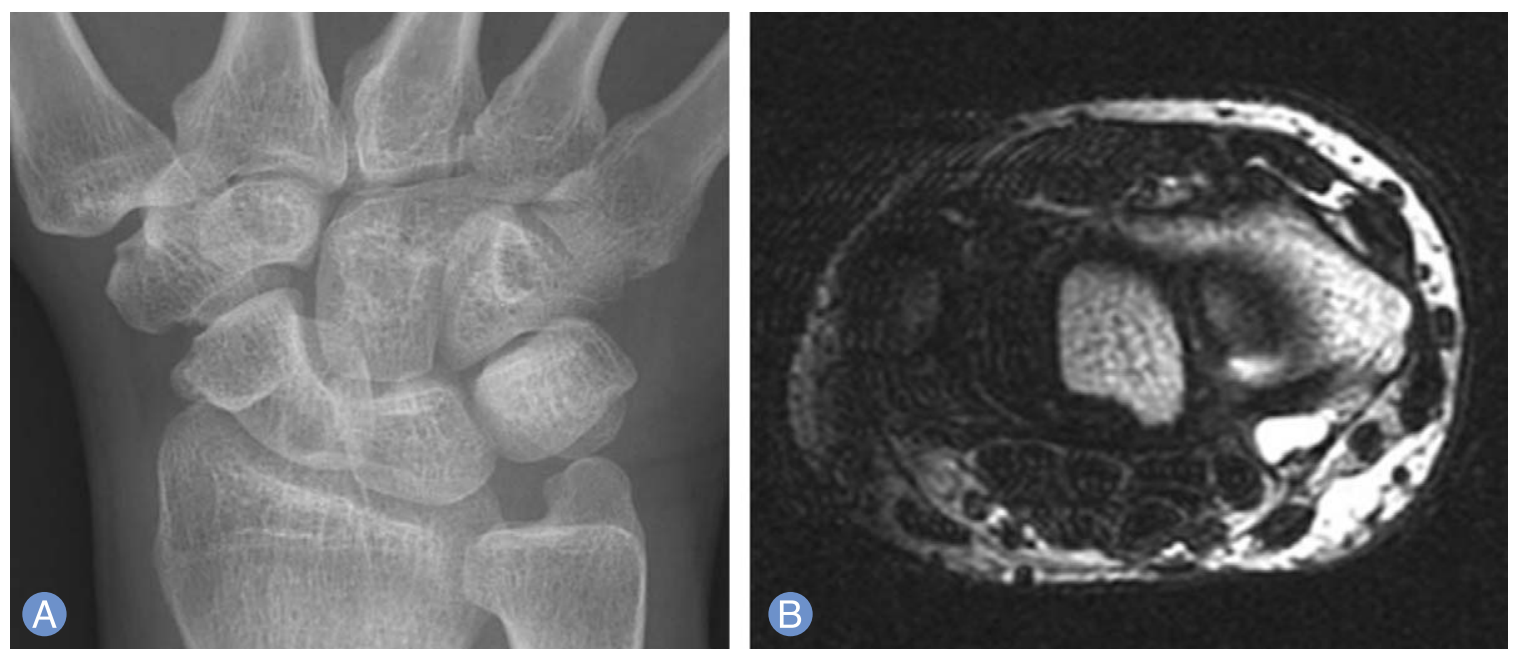

Fig. 4. (A) Anteroposterior radiograph of wrist shows radiolucent lesion on scaphoid. (B) Axial T1-weighted magnetic resonance imaging shows slightly hypointensity signal change close to the volar soft tissue ganglion.
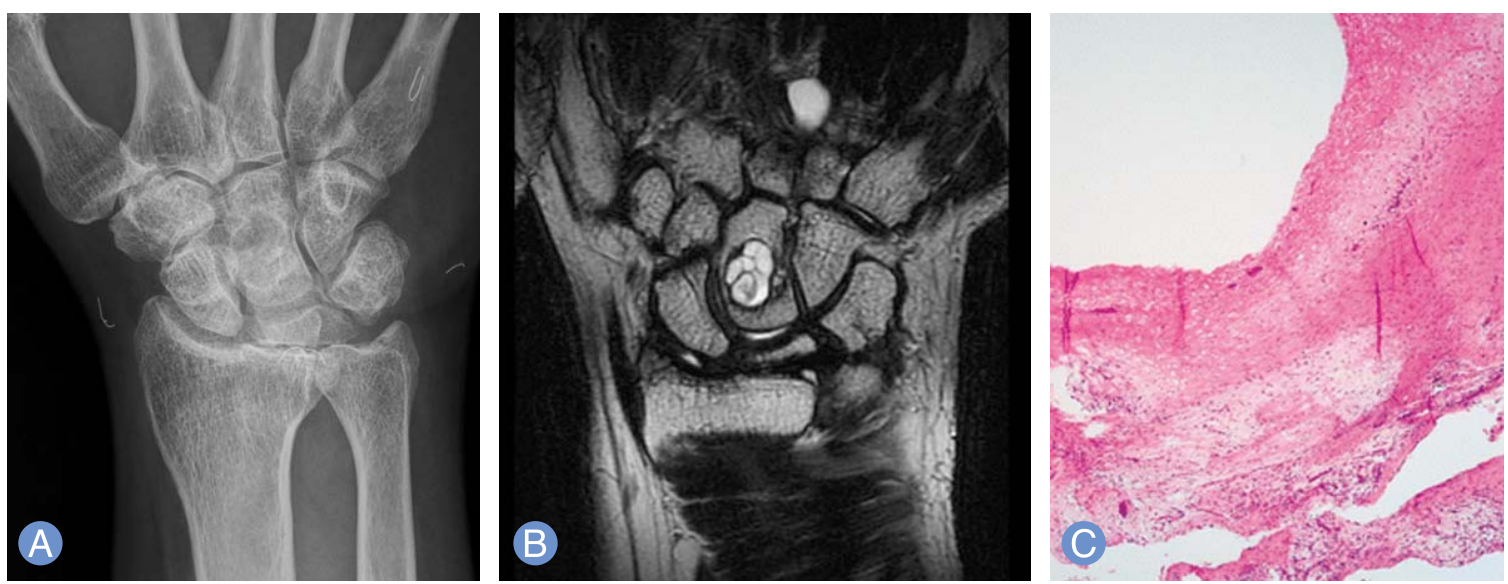

Fig. 5. (A) Anteroposterior radiograph of wrist shows radiolucent lesion on capitate. (B) Coronal T1-weighted magnetic resonance imaging shows tissue ganglion non-communicating with intra-osseous bone cyst on capitate. (C) The histology shows a multiloculated, cystic lesion with foci of myxoid degeneration in the surrounding stroma $(\mathrm{H} \& \mathrm{E}, \times 40)$. 
2), 골낭종이 피질골의 천공을 유발한 경우를 type II, 6예 (intraosseous lesion with cortical perforation, case 2) (Fig. 3)로, 또한 연부조직 결절종과 골낭종이 동일 수근골 주 위에서 병합 발생 되어 두 병소가 연결되어 있는 경우를 type III, 2예(coexisting soft tissue ganglion communicating with intraosseous lesion, case 3) (Fig. 4), 연결되지 않은 경우를 type IV, 1예(coexisting soft tissue ganglion noncommunicating with intraosseous lesion, case 4) (Fig. 5) 로 분류하였다.

수근부 골낭종의 발병기전은 논란의 여지가 있으나, 일반적 으로 2 가지 병인론이 있다. 첫째는 내인성 원인으로 수근골내 결합조직인 활액막의 퇴행변화이거나 완관절의 외력에 따른 연골하 손상등의 일차 골내병변이고, 둘째는 외인성 원인으로 연부조직 결절종의 수근골내 피질골 침투에 의한 골내 낭종성 병변이다. 2005년 Van den Dungen 등은 본 연구의 type III에서와 같이 완관절의 연부조직 낭종이 인접 수근골 낭종의 원인이 될 수 있다고 하였으나, 본 연구에서는 골낭종만이 발 생된 경우는 23 예(88.5\%)임에 반해, 인근 연부조직 결절종과 병합 발병한 경우는 단지 2예(8\%)뿐 이여서, 첫째 내인성 병 인론이 더 설득력이 있었으며, Schajowicz 등과 Logan 등도 저자들의 결론과 일치한다.

Uriburu와 Levy ${ }^{2}$ 는 주상골과 월상골에 발생한 15 예의 골내 낭종 중, 6 예에서 연부 조직 결절종과의 골내 낭종의 피질골 결손을 통한 연결이 있었다고 하였는데, 이는 본 연구의 제II 형에 해당하며, 다소 많은 병합 발생빈도였으나, 그외 완관절 통증과 운동제한 등의 증상이 심해 수술적 치료가 필요하였던 점 등은 본 연구의 결과와 동일 하였다. 또한 Tham과 Ireland ${ }^{14}$ 는 월상골에 발생한 골내 낭종 9 예를 보고 하였는데, 이를 저자들의 분류에 적용해 보면, type I이 5예, type II가 2 예, type III가 2예로써, 내인성 발생 기전에 해당하는 type I 과 II가 외인성 기전에 의한 type III보다 많은 빈도를 보였다.

그 외 Schajowicz 등도 88예의 골내 낭종 중 14예(16\%)만 이, 또한, Kambolis 등도 15예의 골내 낭종 중 4예(26\%)에서 만 본 연구에서의 III형과 같은 골낭종과 인접부위의 연부조직 낭종(extraosseous juxta-cortical ganglion)과 직접적인 연 결이 있었다고 보고 하였다.

이상의 문헌상 발생 원인들과, 그외 본 연구에서 확인된 중 년기 여성의 요골측 수근열(radial wrist column)에 수근골 골낭종이 호발하는 것은 골다공증과 퇴행성 완관절염의 진행 과 완관절의 외측에 지속적으로 가해지는 축성압력(axial loading)과도 관련성이 있을 것으로 보아, 발병 원인과 병합하 여 적합한 치료 등, 이들에 대한 향후 지속적 연구가 필요할
것으로 판단된다.

\section{결론}

수근골 골낭종은 MRI상 명백한 4가지 형태로 구분될 수 있 으며, 연부 조직 결절종을 동반하지 않은 수근골내 골낭종이 대부분인 것으로 보아 일차적 골내 내인성 골 병변임을 시사 한다.

\section{REFERENCES}

1. Schajowicz F, Clavel Sainz M, Slullitel JA. Juxta-articular bone cysts (intra-osseous ganglia): a clinicopathological study of eighty-eight cases. J Bone Joint Surg Br. 1979;61:107-16.

2. Uriburu IJ, Levy VD. Intraosseous ganglia of the scaphoid and lunate bones: report of 15 cases in 13 patients. J Hand Surg Am. 1999;24:508-15.

3. Lorente R, Moreno M, Quiles M. Bilateral intraosseous ganglia of the lunate: a case report. J Hand Surg Am. 1992;17:1084-5.

4. Logan SE, Gilula LA, Kyriakos M. Bilateral scaphoid ganglion cysts in an adolescent. J Hand Surg Am. 1992;17:490-5.

5. Bowers WH, Hurst LC. An intraarticular-intraosseous carpal ganglion. J Hand Surg Am. 1979;4:375-7.

6. Posner MA, Green SM. Intraosseous ganglion of a phalanx. J Hand Surg Am. 1984;9:280-2.

7. Kambolis C, Bullough PG, Jaffe HI. Ganglionic cystic defects of bone. J Bone Joint Surg Am. 1973;55:496-505.

8. Iwahara T, Hirayama T, Takemitu Y. Intraosseous ganglion of the lunate. Hand. 1983;15:297-9.

9. Suh JS, Lee SM, Kim DS. Intraosseous ganglion in capitate: a case report. J Korean Soc Surg Hand. 2003;8:814.

10. Han CW, Kim JC, Lee HK, Ha JD, Shin YH, Kim WY. Intraosseous ganglion of the lunate. J Korean Soc Surg Hand. 2003;8:47-9.

11. Park MR, Lee GH, Kim SH. Intraosseous ganglion in triquetrum: a case report J Korean Orthop Assoc. 2000;35:661-3.

12. Kligman M, Roffman M. Bilateral intraosseous ganglia of the scaphoid and lunate bones. J Hand Surg Br. 1997;22:820-1.

13. Van den Dungen S, Marchesi S, Ezzedine R, Bindou D, 
J Korean Soc Surg Hand Vol. 19, No. 1, March 2014

Lorea P. Relationship between dorsal ganglion cysts of the wrist and intraosseous ganglion cysts of the carpal bones. Acta Orthop Belg. 2005;71:535-9.
14. Tham S, Ireland DC. Intraosseous ganglion cyst of the lunate: diagnosis and management. J Hand Surg Br. 1992;17:429-32.

\section{수근골 골낭종의 임상 양상과 치료}

이철형' · 선동혁 1 이윤민 · 송석환 ${ }^{2} \cdot$ 이승구 ${ }^{1}$

'대전 선병원 정형외과, ${ }^{2}$ 가톨릭대학교 의과대학 여의도성모병원 정형외과

서론: 저자들은 과거 10 년간 치험한 수근골 골낭종 27 예를 대상으로 수근골의 발생 분포, 발생 원인 및 치료 결과를 보 고하고자 한다.

방법: 2002년 2월부터 2013년 7월까지 양측 완관절 이환 5예를 포함한 20명, 총 27예(다발성 2예)의 수근골 골낭종을 평균 16.6 개월간 추적 관찰하였다. 완관절 연부조직 낭종과의 연관 관계 등 발병 원인을 조사하였고, 치료 후 최종 추시 시 완관절의 동통 및 운동 범위, 방사선 소견, 환자의 만족도 등을 평가하였다.

결과: 발생 부위는 수근골 중 월상골이 12 예, 삼각골이 5 예, 주상골 6 예 및 유두골 2 예, 대다각골 2 예로 완관절의 축성 압력(axial loading)이 가해지는 요골측 수근열(radial ray) 측이 많았다. 보전적 치료를 한 2예를 제외한, 총 25예의 발생 기전에 따른 분류는 자기공명영상상 수근골 골낭종만 있었던 예(제I형)가 16 예, 그 외 피질골이 천공되었거나(제II 형, 6예), 주변 연부조직 결절종과 동반된 경우는 2예(제III형), 그리고, 동반되지 않은 경우(제IV형)가 1예였다.

결론: 수근골 골낭종은 자기공명영상상 명백한 4가지 형태로 구분될 수 있으며, 연부 조직 결절종을 동반하지 않은 수 근골내 골낭종이 대부분인 것으로 보아 일차적 골내 내인성 골 병변임을 시사한다.

색인단어: 골낭종, 수근골

접수일 2013년 12월 31일 수정일 2014년 2월 24일

게재확정일 2014년 2월 26일

교신저자 이승구

대전 중구 목중로 29

대전 선병원 정형외과

TEL 042-220-8460, FAX 042-252-1911

E-mail skrhee@catholic.ac.kr 